\title{
Cytoprotective Activity of Polyamines Is Associated with the Alternative Splicing of RAD51A Pre-mRNA in Normal Human $\mathrm{CD}^{+} \mathrm{T}$ Lymphocytes
}

\author{
Yulia A. Gladilina ${ }^{1}$, Lylia Bey ${ }^{2}$, Abdullah Hilal ${ }^{1}$, Ekaterina V. Neborak ${ }^{2}$, Varvara G. Blinova ${ }^{1}$ \\ and Dmitry D. Zhdanov $1,2, *$ (D)
}

1 Institute of Biomedical Chemistry, Pogodinskaya St. 10/8, 119121 Moscow, Russia; leonova_y@mail.ru (Y.A.G.); hilalabdullahh@gmail.com (A.H.); varya.blinova@list.ru (V.G.B.)

2 Department of Biochemistry, Peoples' Friendship University of Russia (RUDN University), Miklukho-Maklaya St. 6, 117198 Moscow, Russia; beylylia60@gmail.com (L.B.); neborak-ev@rudn.ru (E.V.N.)

* Correspondence: zhdanovdd@gmail.com

\section{check for}

updates

Citation: Gladilina, Y.A.; Bey, L.; Hilal, A.; Neborak, E.V.; Blinova, V.G.; Zhdanov, D.D. Cytoprotective Activity of Polyamines Is Associated with the Alternative Splicing of RAD51A Pre-mRNA in Normal Human $\mathrm{CD}^{+}{ }^{+} \mathrm{T}$ Lymphocytes. Int. J. Mol. Sci. 2022, 23, 1863. https:// doi.org/10.3390/ijms23031863

Academic Editors: Christos

K. Kontos and Pinelopi I. Artemaki

Received: 18 January 2022

Accepted: 5 February 2022

Published: 7 February 2022

Publisher's Note: MDPI stays neutral with regard to jurisdictional claims in published maps and institutional affiliations.

Copyright: (C) 2022 by the authors. Licensee MDPI, Basel, Switzerland. This article is an open access article distributed under the terms and conditions of the Creative Commons Attribution (CC BY) license (https:// creativecommons.org/licenses/by/ $4.0 /)$.

\begin{abstract}
Physiological polyamines are ubiquitous polycations with pleiotropic biochemical activities, including regulation of gene expression and cell proliferation as well as modulation of cell signaling. They can also decrease DNA damage and promote cell survival. In the present study, we demonstrated that polyamines have cytoprotective effects on normal human $\mathrm{CD}^{+}{ }^{+} \mathrm{T}$ lymphocytes but not on cancer Jurkat or K562 cells. Pretreatment of lymphocytes with polyamines resulted in a significant reduction in cells with DNA damage induced by doxorubicin, cisplatin, or irinotecan, leading to an increase in cell survival and viability. The induction of RAD51A expression was in response to DNA damage in both cancer and normal cells. However, in normal cells, putrescin pretreatment resulted in alternative splicing of RAD51A and the switch of the predominant expression from the splice variant with the deletion of exon 4 to the full-length variant. Induction of RAD51A alternative splicing by splice-switching oligonucleotides resulted in a decrease in DNA damage and cell protection against cisplatin-induced apoptosis. The results of this study suggest that the cytoprotective activity of polyamines is associated with the alternative splicing of RAD51A pre-mRNA in normal human $\mathrm{CD}^{+} \mathrm{T}$ lymphocytes. The difference in the sensitivity of normal and cancer cells to polyamines may become the basis for the use of these compounds to protect normal lymphocytes during lymphoblastic chemotherapy.
\end{abstract}

Keywords: polyamines; alternative splicing; DNA damage; cytoprotection; apoptosis

\section{Introduction}

Polyamines (PAs) are small polycationic molecules derived from the metabolism of ornithine by the enzyme ornithine decarboxylase [1]. Spermine (Spm), spermidine (Spd), and putrescine (Put) are three main PAs found in all types of human cells and tissues [2]. Due to their positive charge, PAs are able to bind most biological polymers. The binding of PAs to proteins results in modulation of the activity of different enzymes [3] and ion channels [4] that support the functions of cell membranes. Due to their ability to interact with nucleic acids, PAs are able to influence gene transcription [5,6] and mRNA translation $[7,8]$. Thus, PAs are essential for different cellular functions, including cell growth and proliferation [9]. Several works have demonstrated that PAs have antioxidative effects [10], can promote homology-directed DNA repair [11], and downregulate DNA damage-associated cell death $[12,13]$. Almost all cells can produce PAs, but their production is especially high in rapidly growing cells; therefore, the concentration of PAs as well as the gene expression and activity of enzymes involved in PA biosynthesis are higher in cancer tissues than in normal surrounding tissues [14-16]. Therefore, the pathway of PA metabolism is a promising target for chemotherapy and chemoprevention [17]. PAs have 
roles in normal immune cell function [18] and are responsible for $\mathrm{T}$ cell proliferation and differentiation [19]. Thus, an anti-PA chemotherapeutic strategy may have a negative effect on normal immune cells. To support this, catabolic products of PA oxidation are toxic and can induce apoptosis in normal and tumor cells [20-23]. Several works have demonstrated that the ability of PAs to induce a cellular response to DNA damage is associated with the RAD51 DNA repair system $[11,24]$. To date, there are no works comparing the ability of PAs to influence DNA damage and the survival of cancer and normal cells. In the present study, we demonstrated that PAs have cytoprotective effects on normal human $\mathrm{CD} 4^{+} \mathrm{T}$ lymphocytes but not on Jurkat or K562 cancer cells, and such protection is associated with the induction of the alternative splicing of RAD51 pre-mRNA.

\section{Results}

\subsection{Polyamines Have Cytoprotective Activity against Normal $C D 4^{+} T$ Cells but Not against Malignant Cells}

It is known that PAs can suppress or induce immune cell growth depending on their concentration in cell media $[25,26]$. We tested the ability of Spm, Spd, or Put to affect cell growth at a concentration of $10 \mu \mathrm{M}$ using the MTT test. The results are shown in Figure $\mathrm{S} 1 \mathrm{~A}, \mathrm{~B}$ in the Supplementary File. All three PAs at this concentration did not show significant activity to induce or suppress the growth of either Jurkat or K562 cancer cells or normal activated $\mathrm{CD}^{+} \mathrm{T}$ lymphocytes (Figure 1A). The results of the MTT test demonstrating the dose-dependent reduction in cell metabolic activity/growth after incubation with DNAdamaging agents are shown in Figure S1D-F in the Supplementary File. The incubation of cancer cells with DNA-damaging agents resulted in significant inhibition of their metabolic activity/growth up to $32.4-68.3 \%$ of control cells, and the addition of each PA did not protect cells against damage (Figure $1 \mathrm{~B}-\mathrm{G}$ ). $\mathrm{CD}^{+} \mathrm{T}$ cells were more sensitive to DNA damage, and only 3.1-20.9\% of cells remained alive after incubation with genotoxic agents (Figure $1 \mathrm{H}-\mathrm{J}$ ). However, pretreatment of $\mathrm{CD}^{+} \mathrm{T}$ cells with PAs resulted in a significant induction of cell metabolic activity / cell growth up to 55.3-122.6\% of control nontreated cells. Representative photos of the MTT assay for these experiments are presented in Figure S2 in the Supplementary File. These results demonstrated that each PA has a cytoprotective effect on normal but not cancer cells. The simplest PA is Put, which originates from ornithine and can be successively converted to both Spd and Spm [27]. Thus, all subsequent experiments were performed with Put as a cytoprotective agent.

\subsection{Polyamines Decrease DNA Damage Induced by Genotoxic Agents in Normal CD4 $4^{+} T$ Cells}

We studied whether Put can decrease the level of DNA damage and performed a TUNEL assay for flow cytometry. Put was not able to significantly reduce the proportion of cells treated with each DNA-damaging agent (Figure 2A-D). However, a significant reduction in TUNEL-positive cells was observed for $\mathrm{CD} 4^{+} \mathrm{T}$ lymphocytes pretreated with Put: by $61.1 \%$ for Dox, $76.6 \%$ for Cis, and $64.8 \%$ for Irt (Figure 2E,F). The results of this experiment demonstrated that Put induced significant downregulation of DNA damage in normal CD4 ${ }^{+} \mathrm{T}$ cells but not in cancer cells. Among the studied cytotoxic agents, $\mathrm{Cis}$ demonstrated the strongest activity to induce DNA damage (up to $96.3 \%$ ), and such an induction was successfully diminished by Put. Consequently, experiments were performed with Cis as a DNA-damaging agent. 

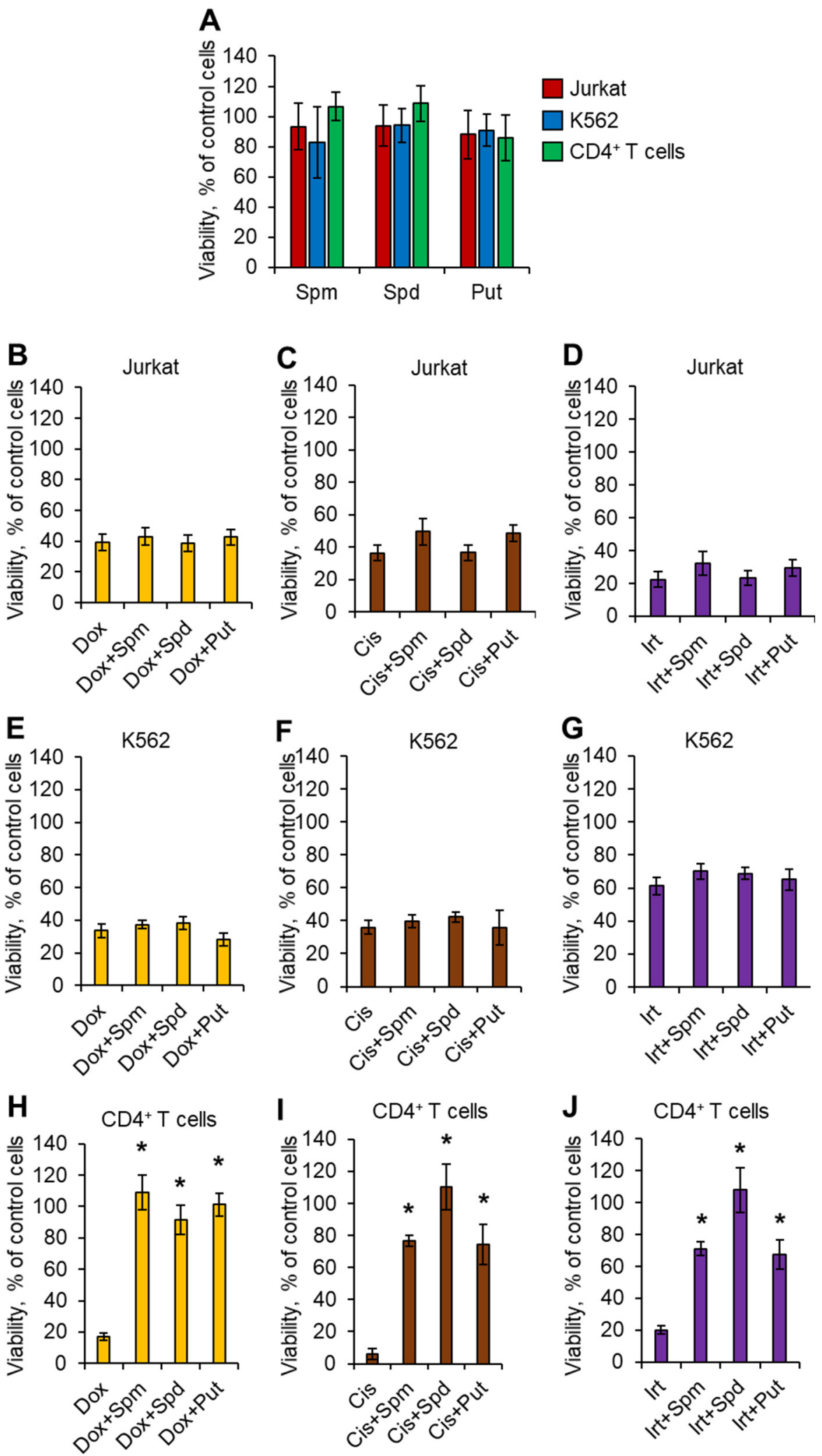

Figure 1. Cytoprotective activity of PAs in normal CD4 ${ }^{+} \mathrm{T}$ cells. (A) Results of the MTT test for cells incubated with $10 \mu \mathrm{M}$ of each PA for $72 \mathrm{~h}$. The results of the MTT test for cancer (B-D) Jurkat, (E-G) K562, or $(\mathrm{H}-\mathrm{J})$ normal CD4 ${ }^{+} \mathrm{T}$ cells incubated with genotoxic agents: $1 \mu \mathrm{M}$ doxorubicin (Dox), $0.5 \mu \mathrm{M}$ cisplatin (Cis), or $1 \mu \mathrm{M}$ irinotecan (Irt) in the presence or absence of each PA. $n=8$. * $p \leq 0.05$ vs. cells not treated with PA. Spd: spermidine; Spm: spermine; Put: putrescine. 

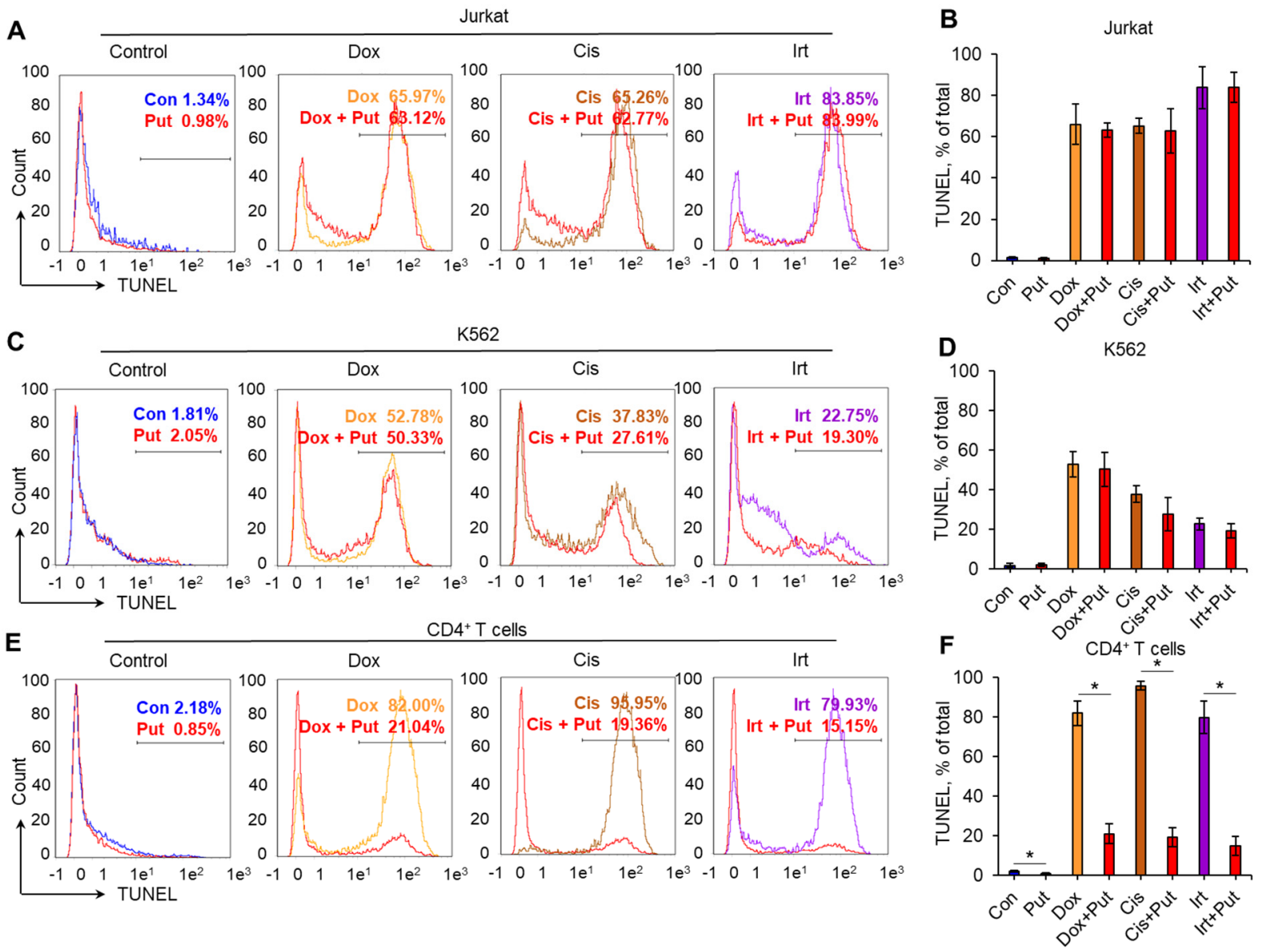

Figure 2. Decreased DNA damage in normal $\mathrm{CD}^{+} \mathrm{T}$ cells pretreated with PAs. Representative terminal deoxynucleotidyl transferase-mediated d-UTP nick end labeling (TUNEL) flow-cytometry diagrams for cancer cell lines (A) Jurkat, (C) K562, or (E) normal CD4 ${ }^{+}$T lymphocytes pretreated with each PA and incubated with genotoxic agents. The results of the TUNEL assay for flow cytometry for treated (B) Jurkat, (D) K562, or (F) CD4 ${ }^{+}$T cells. $n=4 .{ }^{*} p \leq 0.05$. Con: control intact cells; Cis: cisplatin; Dox: doxorubicin; Irt: irinotecan; Spd: spermidine; Spm: spermine; Put: putrescine. $n=4$. $* p \leq 0.05$.

\subsection{Putrescin Prevents the Progression of Apoptosis Induced by Cisplatin in Normal CD4 ${ }^{+} \mathrm{T}$ Cells}

The results of the MTT test do not allow us to answer whether Put prevents cell death, as this assay determines the metabolic status of cells. We measured the induction of cell death by Cis in Put-treated and nontreated cells by labeling phosphatidyl serine on apoptotic cell membranes with annexin V-FITC and cell DNA by PI followed by flow cytometry. The results of the cell death measurement were in good agreement with the results from the MTT test (Figure 1) and with the induction of DNA damage determined by the TUNEL assay (Figure 2). A concentration of $0.5 \mu \mathrm{M}$ Cis could induce apoptotic cell death. $\mathrm{CD}^{+} \mathrm{T}$ lymphocytes and Jurkat cells were the most sensitive (17.3-21.4\% of them remained alive), while K562 cells were more resistant (34.1-39.6\% remained alive) (Figure 3). Pretreatment of cells with Put led to a small and insignificant decrease in the proportion of apoptotic and dead Jurkat (Figure 3A,B) and K562 (Figure 3C,D) cell lines. However, pretreatment of normal CD4 ${ }^{+} \mathrm{T}$ cells with Put resulted in significant prevention of cell death, and more than $80 \%$ of cells remained alive after the induction of apoptosis with Cis (Figure 3E,F). The results of this experiment indicate that PAs can prevent cell death associated with DNA damage in normal lymphocytes but not in cancer lymphocytes. 

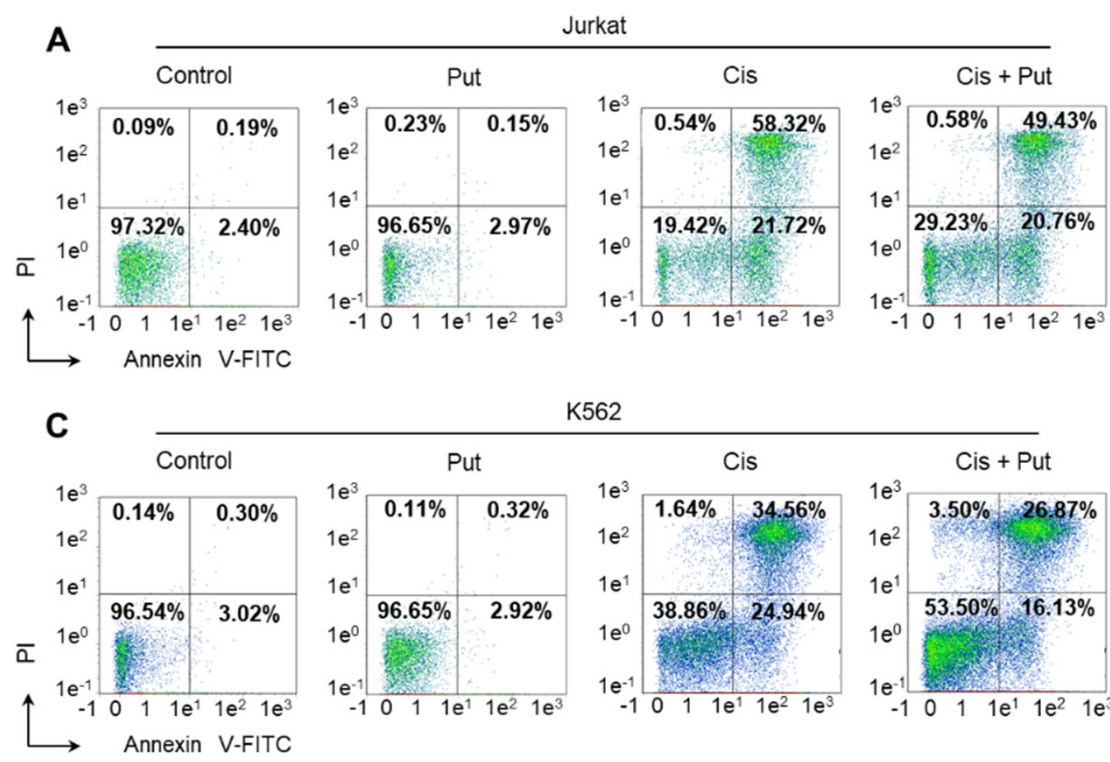

K562
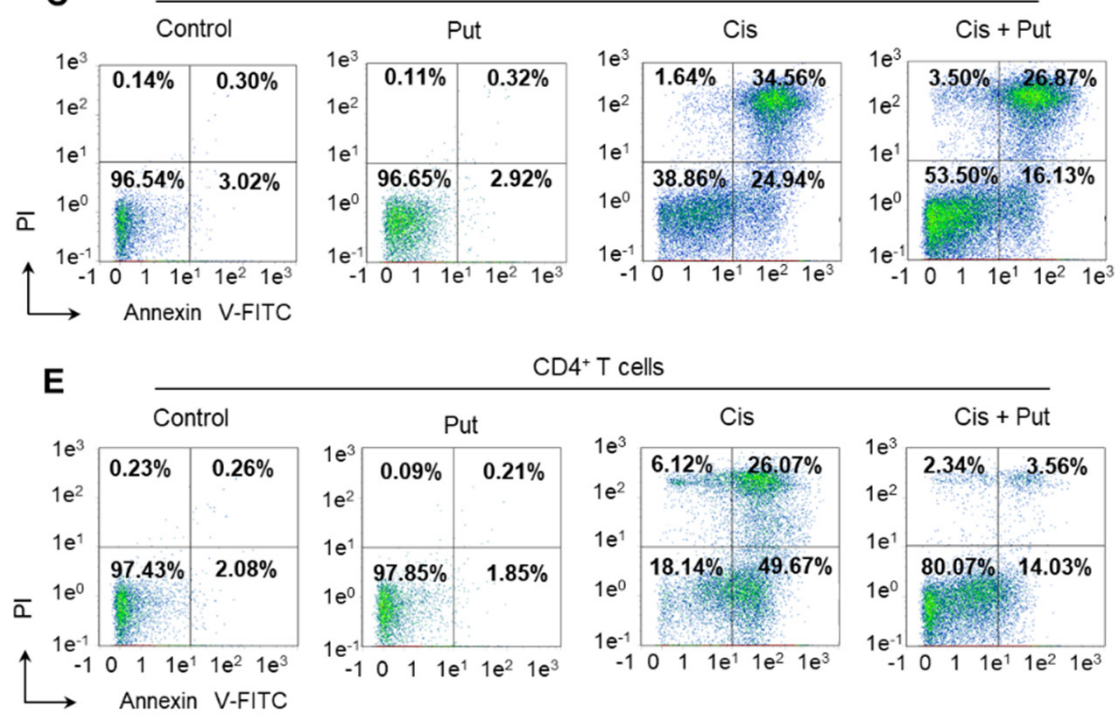

CD4 ${ }^{+} \mathrm{T}$ cells

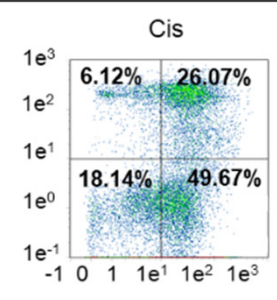

B

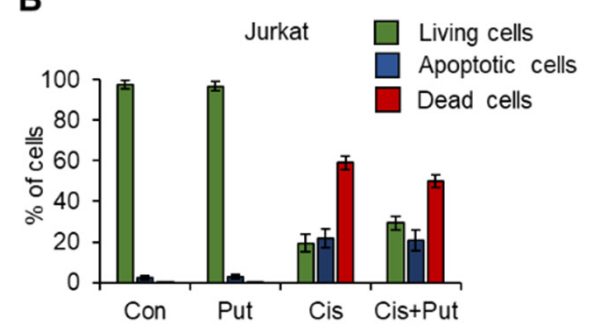

D
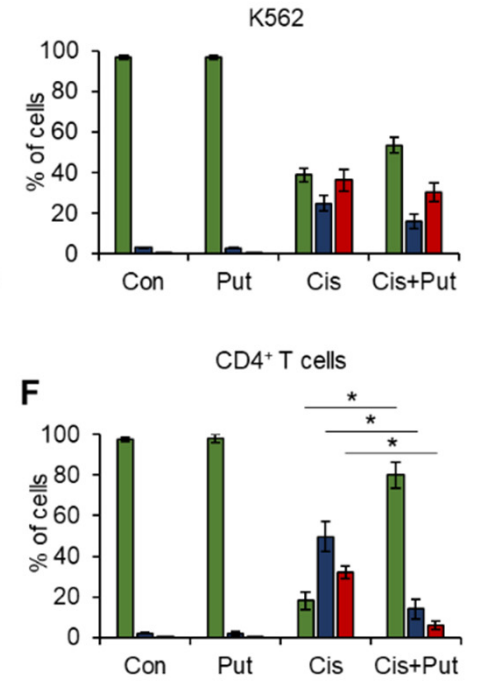

Figure 3. Prevention of cisplatin-induced apoptosis by putrescin (Put) in normal CD4 ${ }^{+} \mathrm{T}$ cells. Cells were labeled with annexin V-FITC and propidium iodide, and flow cytometry was performed $72 \mathrm{~h}$ after incubation with cisplatin (Cis). Representative plots for cancer cell lines (A) Jurkat, (C) K562, or (E) normal CD4 $4^{+} \mathrm{T}$ lymphocytes pretreated with Put and incubated with Cis. The proportions of live cells (lower left quadrants), apoptotic cells (lower right quadrants), and dead cells (two upper quadrants) are presented. (B,D,F) Histograms of live, apoptotic, and dead cells measured by flow cytometry. $n=4 .{ }^{*} p \leq 0.05$.

\subsection{Cisplatin Induces RAD51A but No Other RAD51 Family Members in Cancer Cell Lines and Normal $C D 4^{+}$T Cells}

PAs are able to facilitate homologous recombination-mediated DNA repair through the modulation of RAD51 activity [11,24]. Four genes encoding RAD51 paralogs are known in the human genome: $R A D 51 A, R A D 51 B, R A D 51 C$, and $R A D 51 D$ [28]. We investigated the expression levels of each $R A D 51$ family member by real-time RT-PCR in cancer and normal lymphocytes pretreated with Put and incubated with Cis. We observed that $\mathrm{Cis}$ could induce the expression of only RAD51A in cancer and normal cells (Figure 4A-C). Put did not modulate RAD51A expression. The mRNA levels of other RAD51 members, $R A D 51 B, R A D 51 C$, or $R A D 51 D$, were unchanged in all cell types treated with Cis and/or Put. Western blotting results of total RAD51 protein were in agreement with the results from real-time RT-PCR (Figure 4D-G). We observed the induction of RAD51 protein levels in all types of cells treated with Cis. 

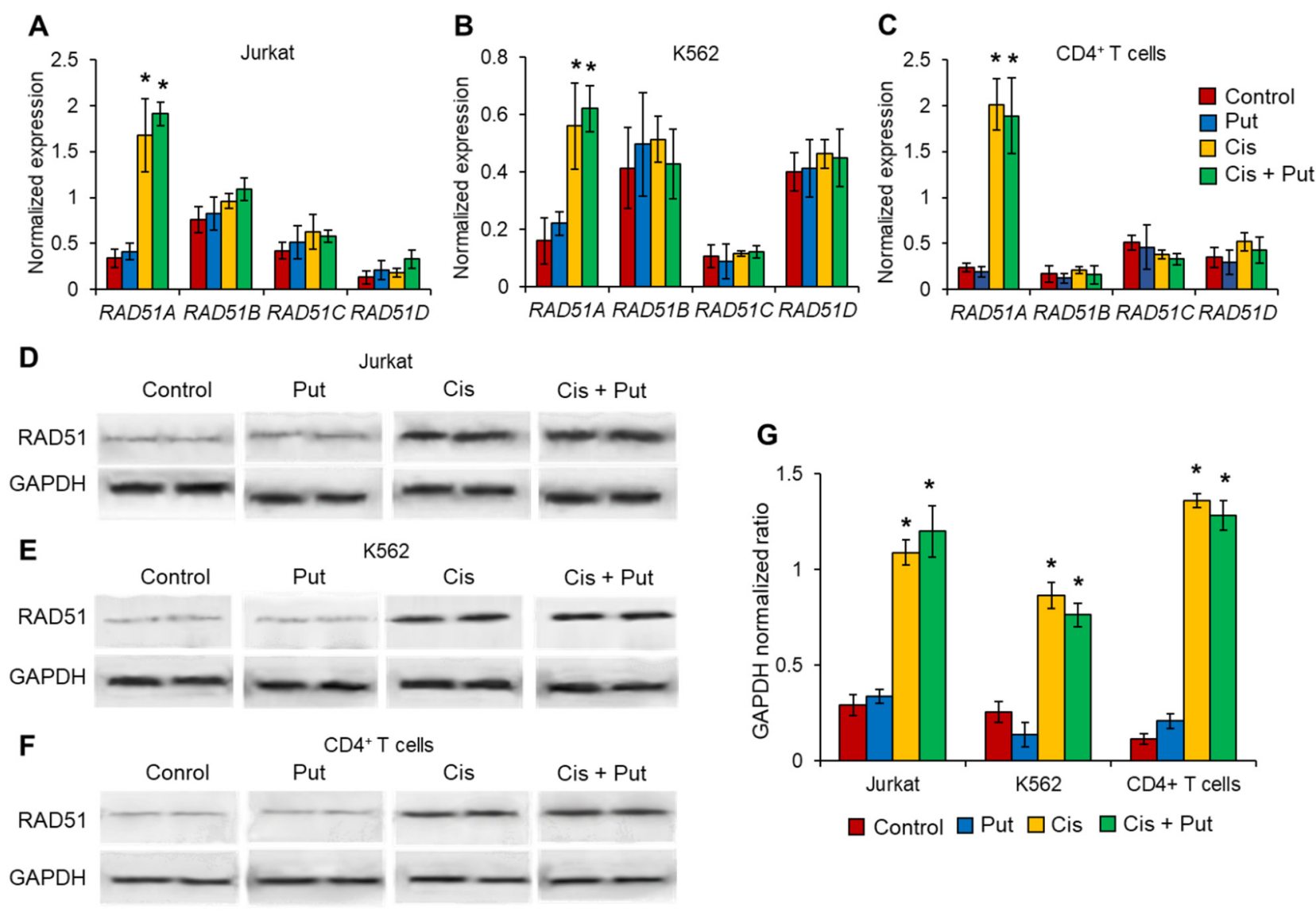

Figure 4. Induced RAD51A expression in cells treated with cisplatin (Cis). mRNA levels of RAD51 members measured by real-time RT-PCR in cancer cell lines (A) Jurkat, (B) K562, or (C) normal $\mathrm{CD}^{+} \mathrm{T}$ lymphocytes pretreated with putrescin (Put) and incubated with Cis. mRNA levels were normalized relative to the expression of the reference gene 18S. (D-F) Western blotting for RAD51 protein and the reference protein GAPDH in treated cells. (G) Results of RAD51 protein quantification relative to GAPDH. $n=4$. ${ }^{*} p \leq 0.05$ vs. control intact nontreated cells.

\subsection{Putrescin Induces Alternative Splicing of RAD51A Pre-mRNA in Normal CD4 $4^{+}$T Cells but Not in Malignant Cells}

The results of previous experiments did not allow us to answer why Put prevented the death of normal $\mathrm{CD}^{+} \mathrm{T}$ cells but not cancer Jurkat or K562 cells. The pre-mRNA of RAD51A is subjected to alternative splicing leading to the induction of three main splice variants: full-length (FL) and truncated splice variants with deletion of exon 4 ( $\Delta 4$ splice variant) or exon 9 ( $\Delta 9$ splice variant) in mature mRNA transcripts. We measured the proportion of mRNA of each RAD51 splice variant in cells pretreated with Put and incubated with Cis by real-time RT-PCR. We observed that neither Put nor Cis was able to significantly shift the proportion of spliced mRNA in both cancer cell lines (Figure 5A,B). In both of these cells, the $\Delta 9$ variant was the predominant variant. The $\Delta 4$ splice variant and FL variant were minor in Jurkat and $\mathrm{K} 562$ cells, respectively. In normal nontreated $\mathrm{CD} 4^{+} \mathrm{T}$ lymphocytes, the predominant variant was $\triangle 4$ (approximately $79.6 \%$ of total RAD51A mRNA), and its proportion did not change after incubation with Cis (Figure 5C) regardless of total RAD51A induction in response to Cis (shown in Figure 4C). We observed significant induction of the proportion of FL variants in $\mathrm{CD}^{+} \mathrm{T}$ cells treated with Put. The proportion of its mRNA increased up to $90.1 \%$ in Put-treated cells and up to $86.4 \%$ in Put-treated Cis-incubated cells. The $\Delta 9$ splice variant was expressed at a minor level and remained almost unchanged in Put- and/or Cis-treated cells. The results of this experiment indicate that the prevention of $\mathrm{CD}^{+} \mathrm{T}$ cell death in response to Put is associated with the induction of alternative splicing of RAD51A pre-mRNA, leading to the dominant expression of FL RAD51. 
A

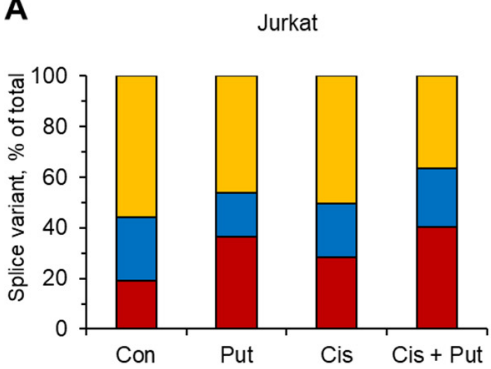

B

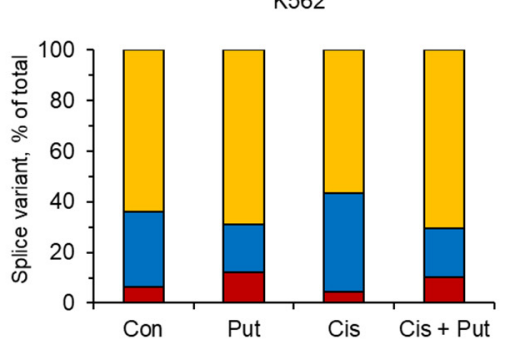

C

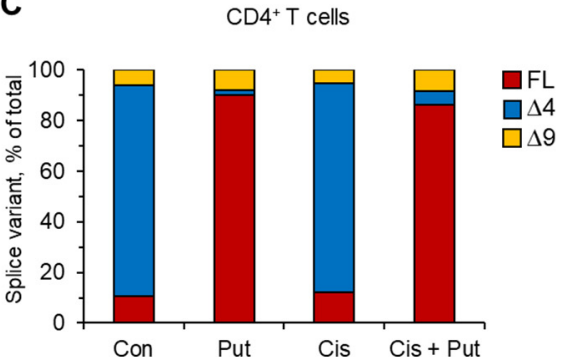

Figure 5. Induction of alternative splicing of RAD51A pre-mRNA by Put. mRNA levels of RAD51 splice variants measured by real-time RT-PCR in cancer cell lines (A) Jurkat, (B) K562, or (C) normal $\mathrm{CD}^{+} \mathrm{T}$ lymphocytes pretreated with Put and incubated with cisplatin (Cis). mRNA levels of splice variants were normalized relative to the expression of the reference gene 18S. $n=4$. FL: full-length splice variant. $\Delta 4$ : mRNA splice variant with the deletion of exon $4 . \Delta 9$ : mRNA splice variant with the deletion of exon 9 .

2.6. Induction of the Full-Length RAD51A Splice Variant with Splice-Switching Oligonucleotides Leads to the Protection of $C D 4^{+} T$ Cells against Cisplatin

To further examine the involvement of $R A D 51 A$ alternative splicing in the prevention of Cis-induced cell death, we modulated it with SSO, which can switch alternative splicing toward the FL variant (Figure 6). $\mathrm{CD}^{+} \mathrm{T}$ lymphocytes were transfected with a 26-mer oligonucleotide complementary to $R A D 51$ pre-mRNA and base pairing with the binding sites located in intron 3 of the splicing regulator protein SF2/ ASF [29,30].

A

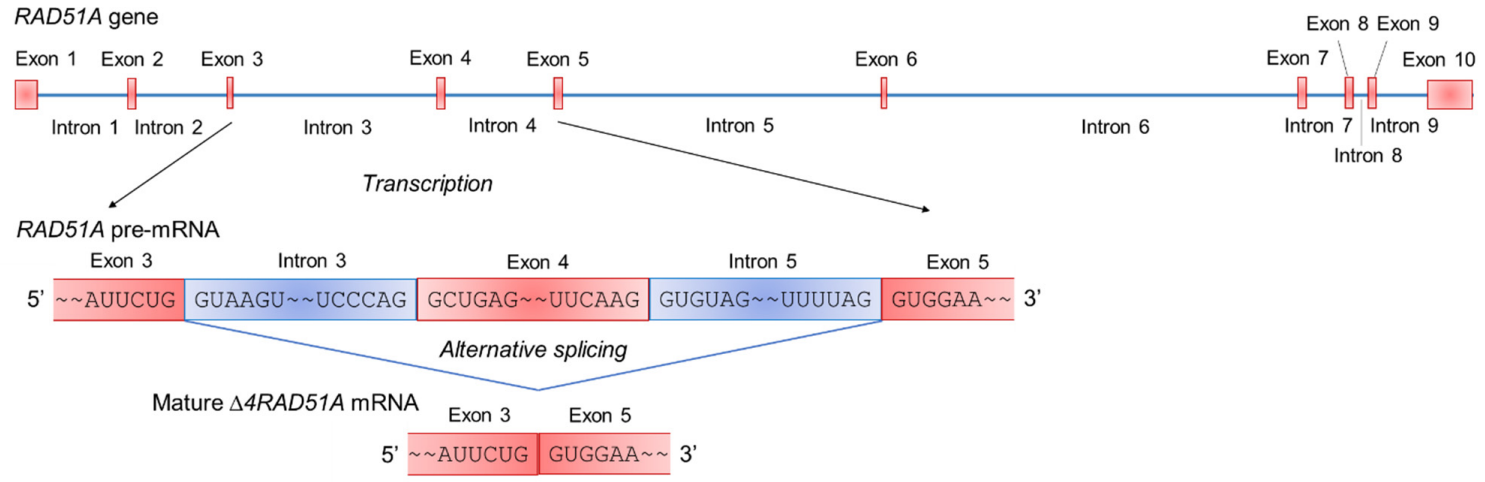

B RAD51A pre-mRNA

C

RAD51A pre-mRNA

SSO 3' GGTAGTTCTAGTGACACCATTCCTTA 5'

||||||||||||||||||||||||||

Intron 3

Exon 4

5' UUUUGCCAUCAAGAUCACUgUGGUAAGGAAUAUUAUUUUGUUGAUUUAAUAUUUCUUAUUUUUCCCAG GCUGAgGCAGCUAAAUUAGUU 3

Figure 6. Schematic presentation of RAD51A alternative splicing. (A) Deletion of exon 4 as a result of alternative splicing and maturation of $\triangle 4 R A D 51 A$ mRNA. (B) Splicing regulator proteins SF2/ASF (shown as a green ellipse) interact with its binding sites (shown in bold red font) within intron 3 of RAD51A pre-mRNA. (C) Cell transfection with the 26-mer-specific antisense SSO for RAD51A (presented in red italic font) blocks the SF2/ASF proteins from binding to their binding sites. Exons are shown as red boxes, and introns are shown as blue boxes. 
Forty-eight hours post-transfection, the transfection efficiency for both SSO and control nonspecific oligonucleotides was 97.01-98.4\% (Figure 7A-D). Transfected cells were incubated with $0.5 \mu \mathrm{M}$ of Cis. The mRNA levels of RAD51A and its splice variants were measured in the transfected cells incubated with Cis. Real-time RT-PCR revealed a more than fivefold increase in total RAD51 expression in Cis-incubated cells transfected with all nucleotides (Figure 7E). Western blotting results of total RAD51 protein were in agreement with the results from real-time RT-PCR (Figure 7F,G). We observed the induction of RAD51 protein levels in transfected cells in response to treatment with Cis. Transfection of cells with SSO to RAD51A pre-mRNA resulted in significant induction of the FL variant and downregulation of the $\Delta 4$ splice variant in both Cis-treated and nontreated cells (Figure $7 \mathrm{H}$ ). Control nonspecific oligonucleotides were not able to modulate alternative splicing or to induce FL variants. The mRNA level of the $\Delta 9$ splice variant remained unchanged in transfected cells regardless of incubation with Cis. This experiment demonstrated that the greatest contribution to the increase in total RAD51A in SSO-transfected cells is made by an increase in the amount of FL splice variant, and the predominance of FL variant is saved for Cis-treated cells. Next, we investigated the influence of SSO transfection on cell survival. Induction of RAD51A alternative splicing with SSO significantly decreased the proportion of cells having DNA damage induced by Cis, which was detected by TUNEL assay and flow cytometry (Figure 7I,J). Cis-treated cells transfected with control oligonucleotides did not prevent DNA damage in cells. Transfection of cells with SSO led to the prevention of apoptotic cell death. A total of 79.2-85.9\% of SSO-transfected cells were alive after Cis treatment, while only $16.4-30.6 \%$ of cells transfected with control 26-mer oligonucleotides remained alive (Figure $7 \mathrm{~K}, \mathrm{~L}$ ). This observation was in accordance with the results of the MTT test, which showed that SSO-transfected cells were more resistant to Cis (Figure 7M-O). The viability of cells transfected with SSO and treated with Cis did not differ from that of nontransfected cells, while Cis treatment of cells transfected with control oligonucleotides resulted in a decrease in viability up to $24.2-35.6 \%$. The results of this experiment demonstrated that the induction of the alternative splicing of $R A D 51 A$ pre-mRNA toward the FL variant using antisense SSO results in the protection of cells against DNA damage and cell death.

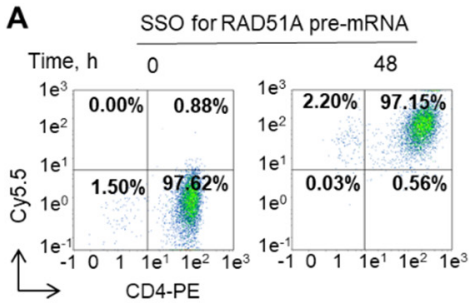

B
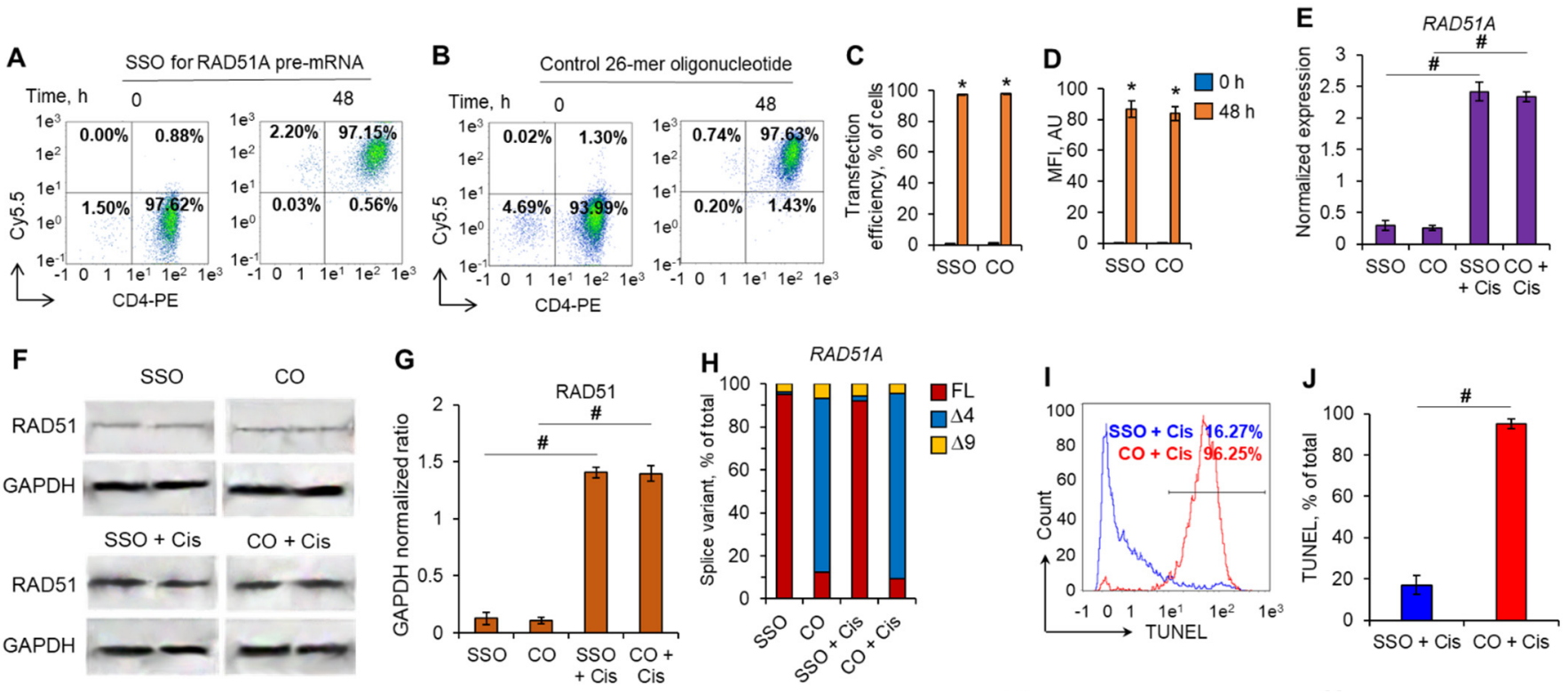

Figure 7. Cont. 

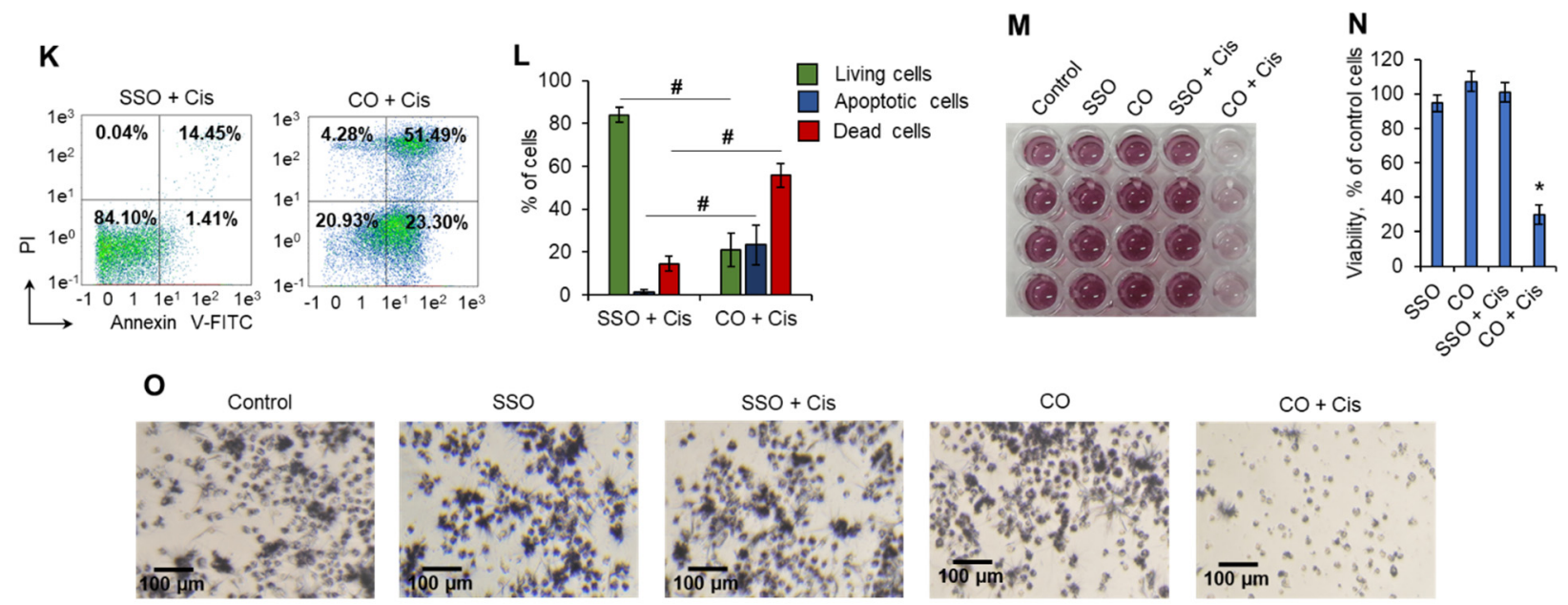

Figure 7. Modulation of $R A D 51 A$ alternative splicing results in $\mathrm{CD}^{+} \mathrm{T}$ cell protection against cisplatin-induced apoptosis. Transfection efficiency of $\mathrm{CD}^{+} \mathrm{T}$ cells. Representative flow cytometry plots of cells transfected with Cy5.5-labeled (A) SSO for RAD51A or (B) a control 26-mer oligonucleotide $72 \mathrm{~h}$ posttransfection. (C) Efficiency of transfection. (D) Mean fluorescence intensity (MFI) of Cy5.5-positive cells. (E) mRNA levels of RAD51A measured by real-time RT-PCR in transfected CD4 ${ }^{+}$ T lymphocytes incubated with cisplatin. mRNA levels were normalized relative to the expression of the reference gene 18S. (F) Western blotting for RAD51 protein and the reference protein GAPDH in transfected cells incubated with cisplatin. (G) Results of RAD51 protein quantification relative to GAPDH. (H) mRNA levels of RAD51A splice variants measured by real-time RT-PCR in CD4 ${ }^{+}$T cells. (I) Representative TUNEL flow cytometry diagrams for cells transfected with oligonucleotides and incubated with cisplatin. (J) Results of TUNEL assay for flow cytometry. (K) Representative flow cytometry plots for cells labeled with annexin V-FITC and propidium iodide after transfection with oligonucleotides and incubation with cisplatin. The proportions of live cells (low left quadrants), apoptotic cells (low right quadrants), and dead cells (two upper quadrants) are presented. (L) Histograms of live, apoptotic, and dead cells measured by flow cytometry. (M) Representative photo of the MTT test for transfected $\mathrm{CD}^{+}{ }^{+} \mathrm{T}$ lymphocytes incubated with cisplatin. (N) Results of MTT test quantification. (O) Bright-field optical images of the MTT test for transfected $\mathrm{CD} 4^{+} \mathrm{T}$ cells exposed to Cis. AU: arbitrary units; Cis: cisplatin; CO: control nonspecific oligonucleotide; FL: full-length splice variant. SSO: splice-switching oligonucleotide. $\Delta 4$ : mRNA splice variant with the deletion of exon 4 . $\Delta$ 9: mRNA splice variant with the deletion of exon 9. $n=4 .{ }^{*} p \leq 0.05$ vs. initial nontransfected cells. $\# p \leq 0.05$.

\section{Discussion}

Most genes of higher eukaryotes have interrupted structures at which coding regions, exons, alternate with noncoding sequences, introns. Gene transcription leads to the formation of pre-mRNA, a molecule that has both exons and introns. During the maturation of mRNA, the splicing of exons and excision of introns by spliceosomes occurs [31]. Posttranscriptional maturation of pre-mRNA plays an essential role in providing biodiversity of protein products encoded by a single gene due to the process of alternative splicing of pre-mRNA. In this process, particular exons, or parts of exons, may be included within or excluded from the final mature mRNA. Consequently, the proteins translated from alternatively spliced pre-mRNAs will contain differences in their amino acid sequence and, often, in their biological functions [32]. An exon may be constitutive (always included in the mRNA) or alternative (may be included or excluded) to generate alternative splice variants. The usage of a splice site may be enhanced or suppressed by its proximity to local cis-regulatory sequences such as exonic splicing enhancers or silencers and intronic splicing enhancers or silencers $[33,34]$. The cis-regulatory sequences are in turn bound by trans-acting factors or splicing factors. Most often, they are serine/arginine-rich proteins (SR proteins). The spliceosome deletes intron and exon ligation during splicing, while the 
functioning of SR proteins is crucial for the determination of the sites that will be deleted or retained.

This study, for the first time, demonstrated a link between PAs, the alternative splicing of $R A D 51 A$ pre-mRNA, and cell protection against cell death due to DNA damage. PAs were able to protect normal activated $\mathrm{CD} 4^{+} \mathrm{T}$ lymphocytes but not Jurkat or $\mathrm{K} 562$ cancer cell lines due to the action of Dox, Cis, or Irt (Figure 1). These cytotoxic compounds are widely used anticancer chemotherapeutics targeting DNA replication and are able to induce double-strain DNA damage by different mechanisms [35-40]. Normal CD4 ${ }^{+} \mathrm{T}$ cells were more sensitive to cytotoxic compounds than cancer cells, as demonstrated by the MTT test (Figure 1), TUNEL assay (Figure 2), and the measurement of live, apoptotic, and dead cells by flow cytometry (Figure 2). However, pretreatment of lymphocytes with each PA resulted in a significant reduction in cells with DNA damage, which increased their survival and viability. All three PAs did not show such an effect on Jurkat and K562 cancer cells and were not able to decrease the rate of DNA damage or increase cell viability. The ability of PAs to reduce oxidative stress and DNA damage is rather well studied [21,41,42], while the precise mechanisms of DNA protection by PAs remain to be determined. One of the early discoveries about PA-DNA interactions was the observation that PAs could stabilize double-stranded DNA due to charge neutralization [43] and by docking into the major or minor grooves [44]. Other researchers directly studied the effect of PA-DNA interactions on double-strand integrity from a structural standpoint $[45,46]$. Later, the promotion of homology-directed DNA repair by PAs due to the activation of RAD51 was described [11]. Our current work belongs to the latter type, where we showed the induction of RAD51A expression in response to DNA damage in cancer and normal cells (Figure 4). However, unlike the above-mentioned study, we demonstrated that PAs can induce alternative splicing of RAD51A pre-mRNA only in normal CD4 ${ }^{+} \mathrm{T}$ cells (Figure 5), and the shift of the pool of RAD51A mRNA from the predominant $\triangle 4$ splice variant toward the FL variant is associated with cell protection. The $R A D 51 A$ gene consists of 10 exons that are subjected to alternative splicing during mRNA maturation (Figure 6A). The most abundant slice variants among murine and human cells are FL, $\Delta 4$, and $\Delta 9$ variants $[47,48]$. Exon 4 encodes the helix-turn-helix region of the protein. Its deletion (i.e., $\Delta 4$ splice variant) results in the loss of the ability to interact with BRCA1 and BRCA2, which may be important for the cellular response to DNA damage. BRCA2 has been shown to regulate both the intracellular localization and DNA-binding ability of this protein [49]. Exon 9 encodes a part of the socalled L2 region loop of the RAD51 protein, and its deletion (i.e., $\Delta 9$ splice variant) abrogates the DNA-binding capacity of the protein [50]. Dominant negative mutations in RAD51 protein variants are suggested to be associated with the Fanconi anemia subtype [51]. Pre-mRNAs of different members of RAD51 are subjected to alternative splicing and are believed to have impacts on cancer progression [52-54]. Our results correspond to the inability of truncated RAD51A splice variants to promote homological recombination and reduce DNA damage because Put induced the predominance of the FL variant and prevented the death of normal $\mathrm{CD}^{+} \mathrm{T}$ cells. Although the questions of why PAs did not induce RAD51A alternative splicing in cancer cells and the mechanism of its induction by PAs remain to be investigated, we demonstrated the involvement of alternative splicing of RAD51A pre-mRNA in cell protection against DNA damage. The modulation of alternative splicing was performed using SSO targeting pre-mRNA of $R A D 51 A$ at the cis-regulatory sequences $5^{\prime}$-GAUCACUG-3', which is the binding site for trans-regulatory SR protein SF2/ ASF [55] (Figure 6B,C). The steric block of such a powerful splicing factor resulted in the predominant expression of the FL splice variant in Cis-treated CD4 ${ }^{+} \mathrm{T}$ cells (Figure 7). The shift of the splicing patterns (Figure $7 \mathrm{H}$ ) was associated with a decrease in DNA damage (Figure 7I,J) and cell protection against Cis-induced apoptosis (Figure 7K-O). The results of this work suggest that the cytoprotective properties of PAs are associated with alternative splicing of $R A D 51 A$ pre-mRNA in normal human $\mathrm{CD}^{+} \mathrm{T}$ lymphocytes but not in cancer cells. The difference in the sensitivity between normal and cancer cells for 
PAs may become the basis for the use of these compounds to protect normal lymphocytes during lymphoblastic chemotherapy.

A number of studies demonstrated the role of RAD51 in cancer progression and the levels of the RAD51 protein are elevated in many cancer cell lines and in primary tumors [56]. RAD51 overexpression can result in improper and hyper-recombination, namely contributing to genomic instability and genetic diversity [57-60]. These, in turn, might drive regular cells towards neoplastic transformation or further contribute to cancer progression. Considering a central role or RAD51 in homological recombination during DNA, it is only logical that its activity is regulated by a set of partner proteins and modulators [5]. We believe that AS of RAD51A represents a mechanism of fine-tuning of DNA repair at the level of modulation of partner protein interaction with RAD51A splice variants. This conclusion must be supported in additional study and the exact role of RAD51A splice variants in cancer progression remains to be determined. However, RAD51 involvement in cell survival in genotoxic conditions and its different abilities for AS in cancer and normal cells makes it a promising target for anticancer applications.

Although most PA-related anticancer strategies are aimed to decrease PAs concentration in tumor cells or tumor microenvironment [61,62], some cell types including leukemia cells remain anergic for PAs at low doses. This promising fact, in case of further study, makes possible the clinical evaluations of polyamines administration in combination with standard chemotherapy.

In conclusion, in our work, we demonstrated for the first time that the induction of alternative splicing of RAD51A pre-mRNA toward FL variant by PAs results in the protection of normal human $\mathrm{CD} 4^{+} \mathrm{T}$ cells against DNA damage. Consequently, PAs can be used for the protection of normal immune cells during DNA-targeting chemotherapy. Unfortunately, the results of this work do not answer the question about the mechanism by which PAs induce alternative splicing of RAD51A pre-mRNA and why this process is abolished in cancer cells. Therefore, future st udies are necessary to resolve these issues. However, this descriptive study demonstrated the impact of PAs on the alternative splicing of $R A D 51 A$ pre-mRNA and demonstrated its role in cell protection against DNA-damageassociated cell death.

\section{Materials and Methods}

\subsection{Cell Purification and Cultivation}

The study was approved by the Ethical Committee of the Institute of Biomedical Chemistry; written informed consent was obtained from all participants. Blood from healthy 18-25-year-old donors ( $n=4)$ was collected in Vacuette K3EDTA tubes (Greiner BioOne, Kremsmünster, Austria). Peripheral blood mononuclear cells (PBMCs) were isolated using Lympholite-H (Cedarlane, Burlington, $\mathrm{ON}$, Canada) density gradient centrifugation. $\mathrm{CD}^{+} \mathrm{T}$ cells were purified from PBMCs using a $\mathrm{CD} 4^{+}$Human Isolation Kit (Miltenyi Biotec, Bergisch Gladbach, Germany) according to the manufacturer's instructions. The purified cells were cultured according to a previously described protocol $[63,64]$. Briefly, CD4 ${ }^{+}$ $\mathrm{T}$ cells were seeded at $5 \times 10^{5}$ cell $/ \mathrm{mL}$ and cultured in $25 \mathrm{~cm}^{2}$ flasks in RPMI 1640 cell medium (Thermo Fisher Scientific Inc., Waltham, MA, USA) supplemented with 10\% FBS (fetal serum bovine, Capricorn Scientific, Ebsdorfergrund, Germany), with $5 \mu \mathrm{g} / \mathrm{mL}$ antiCD28 (eBioscience Inc., San Diego, CA, USA), 5 rg/mL anti-CD3 mAbs (MedBioSpectr, Moscow, Russia), and 100 U/mL rHu IL-2 (R\&D Systems, Minneapolis, MN, USA). Cells were cultivated in $5 \% \mathrm{CO}_{2} / 95 \%$ air in a humidified atmosphere at $37^{\circ} \mathrm{C}$ and restimulated every three days with complete medium supplemented with IL-2 and anti-CD3 and antiCD28 antibodies.

Acute T cell leukemia Jurkat cells and chronic myeloid leukemia K562 cells (both from ATCC, Manassas, VA, USA) were grown in RPMI-1640 supplemented with $5 \%$ fetal bovine serum (Capricorn Scientific, Ebsdorfergrund, Germany) and 1\% sodium pyruvate (Paneco, Moscow, Russia), and cells were grown in $5 \% \mathrm{CO}_{2} / 95 \%$ air in a humidified atmosphere at 
$37^{\circ} \mathrm{C}$. Cell lines were tested for mycoplasma contamination before the experiment using the Mycoplasma Detection Kit PlasmoTest ${ }^{\mathrm{TM}}$ (InvivoGen, San Diego, CA, USA).

\subsection{A. Poptosis Induction and Toxicity Assays}

To induce genotoxicity, Jurkat, K562 or normal CD4 ${ }^{+} \mathrm{T}$ lymphocytes were incubated for $72 \mathrm{~h}$ in 96-well plates (TPP, Trasadingen, Switzerland) with $1 \mu \mathrm{M}$ doxorubicin (Dox, Veropharm, Moscow, Russia), $0.5 \mu \mathrm{M}$ cisplatin (Cis, cis-diamminine-dichloroplatinum(II), Sigma-Aldrich, St. Louis, MO, USA), or $1 \mu \mathrm{M}$ irinotecan (Irt, Veropharm, Moscow, Russia) in the presence of $10 \mu \mathrm{M}$ of each of three PAs: Spm (spermine tetrahydrochloride), Spd (spermidine trihydrochloride), or Put (putrescine dihydrochloride, all from Sigma-Aldrich, St. Louis, MO, USA). The concentrations of PAs and genotoxic drugs were established in preliminary experiments (Figure S1A-C in the Supplementary File). Cell viability was tested by measuring the conversion of the tetrazolium salt 3-(4,5-dimethyl-thiazol-2-yl)-2,5diphenyltetrazolium bromide (Serva, Heidelberg, Germany) to formazan (MTT test). IC50 and IC90 values (the concentration of the enzyme where the response is reduced by $50 \%$ and $90 \%$, respectively) were calculated from curve-fitting equations [65]. Bright-field optical images were acquired using a Leica DMI300 inverted microscope (Leica Microsystems, Wetzlar, Germany).

To measure apoptosis, incubated cells were resuspended in PBS (Paneco, Moscow, Russia) and incubated with annexin V-FITC and propidium iodide (PI) from a FITC Annexin V/Dead Cell Apoptosis Kit (Life Technologies, Carlsbad, CA, USA) according to the manufacturer's protocol. The counting of $5 \times 10^{4}$ cells at each point was performed by flow cytometry with a MACS Quant Analyzer 10 (Miltenyi Biotec, Bergisch Gladbach, Germany) as we previously described [66].

The proportion of cells with DNA damage was estimated by the terminal deoxynucleotidyl transferase-mediated d-UTP nick end labeling (TUNEL) assay $[67,68]$ using the FlowTACS Apoptosis Detection Kit (R\&D Systems, Minneapolis, MN, USA) according to the manufacturer's protocol and flow cytometry.

\subsection{Cell Transfection with Splice-Switching Oligonucleotide}

The transfection of $\mathrm{CD}^{+}$T lymphocytes with 26-mer splice-switching oligonucleotide (SSO) base pairing with RAD51A pre-mRNA or control 26-mer oligonucleotide was performed using Lipofectamine 2000 (Invitrogen, Grand Island, NY, USA) according to the manufacturer's protocol. The nucleotides (custom synthesized by Evrogen, Moscow, Russia) were uniformly modified with 2'-O-(2-methoxy) ethyl sugars (2'MOE), a phosphorothioate backbone, and 5'-methyl cytosine as described in [69] and conjugated with Cy5.5 dye. The SSO sequence is provided in Table 1 and Figure 6B. A BLAST search for SSO target sequences revealed no other perfect sequence matches within the human genome. To determine the efficiency of transfection, the cells were labeled with CD4-phycoerythrin (PE) antibodies (Miltenyi Biotec, Bergisch Gladbach, Germany) according to the manufacturer's protocol, and Cy5.5-positive cells were counted by flow cytometry with a MACS Quant Analyzer 10 (Miltenyi Biotec, Bergisch Gladbach, Germany). The cellular load of the SSO or control oligonucleotide was determined by the mean fluorescence intensity (MFI) of Cy5.5-positive cells.

Table 1. Oligonucleotides used for $\mathrm{CD}^{+} \mathrm{T}$ cell transfection.

\begin{tabular}{cc}
\hline Target & Sequence $\mathbf{( 5}^{\prime} \mathbf{- 3}^{\prime} \mathbf{)}$ \\
\hline SSO for $R A D 51 A$ pre-mRNA & ATTCCTTACCACAGTGATCTTGATGG \\
Control 26-mer oligonucleotide & AUGUGCCGUAGGUGAGGCCUCACGUU \\
\hline
\end{tabular}

\subsection{RNA Isolation and Real-Time RT-PCR}

A previously described protocol was followed [70]. Briefly, total RNA from cells were extracted using a PureLink RNA Mini Kit (Life Technologies, Carlsbad, CA, USA). Five mi- 
crograms of total RNA was reverse-transcribed using the MMLV RT Kit (Evrogen, Moscow, Russia) in a $25 \mathrm{~mL}$ reaction mixture, followed by real-time RT-PCR using DTprime5 (DNA Technology, Protvino, Russia). The reaction mix was prepared using qPCR mix-HS SYBR (Evrogen, Moscow, Russia) according to manufacturer recommendations using the primers listed in Table S1 in the Supplementary File. Two-temperature annealing/extension cycles were used. The fluorescence was measured at the end of the annealing step. Melting curve analyses were performed at the end of the reaction (after the 35th cycle) between $60{ }^{\circ} \mathrm{C}$ and $95^{\circ} \mathrm{C}$ to assess the quality of the final PCR products. The threshold cycles and $\mathrm{C}(\mathrm{t})$ values were calculated by fixing the basal fluorescence at 300 units. The standard curve of the reaction effectiveness was performed using serially diluted mixtures (1:40, 1:80, 1:160, 1:320, and 1:640) of all experimental cDNA samples in duplicate for each gene and 18S RNA separately. Calculation of the relative RNA concentration was performed using DTPrime5 software. Data were presented as ratios of mRNA/18S mRNA.

\subsection{Western Blotting}

Cells were lysed in $1 \mathrm{~mL}$ of TBE buffer ( $89 \mathrm{mM}$ Tris, $89 \mathrm{mM} \mathrm{H}_{3} \mathrm{BO}_{3}, 2 \mathrm{mM}$ EDTA, $\mathrm{pH}=8.0$ ) by ultrasonic disruption $(50 \mathrm{~W}, 2 \mathrm{~min}$ ) using a Sonic Dismembrator (Thermo Fisher Scientific Inc., Waltham, MA, USA). Cell lysates were centrifuged for $10 \mathrm{~min}$ at $12,000 \times g$ to remove cell debris. Protein in samples was measured using the Bradford protein assay (Pierce Biotechnology, Rockford, IL, USA). Bovine serum albumin was used for serial dilutions for the calibration curve. The total protein extracted from cells $(50 \mu \mathrm{g}$ of total protein) was dissolved in $50 \mathrm{mM}$ Tris- $\mathrm{HCl}$ at a $\mathrm{pH}$ of $6.8,1 \%$ sodium dodecyl sulfate, 2 mM EDTA, 1\% 2-mercaptoethanol, and 7.5\% glycerol and denatured by heating at $100{ }^{\circ} \mathrm{C}$ for $10 \mathrm{~min}$. Proteins were separated in gradient PAAG [71] (100 V; $\left.2 \mathrm{~h}\right)$ using NuPAGE ${ }^{\circledR}$ Novex $^{\circledR} 4-12 \%$ Bis-Tris Protein Gels (Life Technologies, Carlsbad, CA, USA). Proteins were transferred onto the nitrocellulose membrane in Novex transferring buffer (Invitrogen, Grand Island, NY, USA) at $40 \mathrm{~V}$ for $3 \mathrm{~h}$. The membranes were stained with Ponceau S (Sigma-Aldrich, St. Louis, MO, USA) [72]. After soaking in the blocking solution Blotting-Grade Blocker (Bio-Rad, Hercules, CA, USA), the membranes were incubated with monoclonal antibodies to glyceraldehyde-3-phosphate dehydrogenase (anti-GAPDH) or anti-RAD51 (both from Abcam, Cambridge, MA, USA) diluted to 1:1000. Membranes were washed in Tris-buffered saline at a $\mathrm{pH}$ of 7.6, with $0.1 \%$ Tween-20 (Invitrogen, Grand Island, NY, USA) and incubated with secondary antibodies conjugated with horseradish peroxidase (Cell Signaling, Danvers, MA, USA). Membranes were visualized using a Super Signal chemiluminescent kit (Pierce Biotechnology) and documented in a ChemiDoc ${ }^{\mathrm{TM}}$ XRS imaging system (Bio-Rad, Hercules, CA, USA). Relative amounts of proteins were determined by densitometry in GelAnalyzer 19.1 (www.gelanalyzer.com, accessed on 17 January 2022).

\subsection{Statistics}

Statistical analysis was performed with 2-way ANOVA and Student's t-test using SPSS 25 software (IBM SPSS Statistics, Armonk, NY, USA). Bonferroni modification of Student's $t$-test was applied as appropriate. The results are expressed as the mean \pm standard error of the mean (SEM). $p \leq 0.05$ was considered significant.

Supplementary Materials: The following supporting information can be downloaded at: https: / / www.mdpi.com/article/10.3390/ijms23031863/s1.

Author Contributions: Y.A.G., E.V.N. and D.D.Z. contributed to the conception and design of the study. Y.A.G., L.B., E.V.N., A.H. and V.G.B. conducted the experiments. Y.A.G. and D.D.Z. contributed to the data analysis and the interpretation of the data. Y.A.G., E.V.N. and L.B. drafted the article. D.D.Z. critically reviewed and commented on the manuscript. All authors have read and agreed to the published version of the manuscript. 
Funding: The study was performed employing "Avogadro" large-scale research facilities, and was financially supported by the Ministry of Education and Science of the Russian Federation, Agreement No. 075-15-2021-933, unique project ID: RF00121X0004.

Institutional Review Board Statement: The study was conducted according to the guidelines of the Declaration of Helsinki, and approved by the Institutional Ethics Committee of the Institute of Biomedical Chemistry, protocol \#029 24 September 2021.

Informed Consent Statement: Informed consent was obtained from all subjects involved in the study. Informed consent for this study is available on request from the corresponding author. The statement is not publicly available due to ethical restrictions.

Data Availability Statement: The data presented in this study are available on request from the corresponding author. The data are not publicly available due to ethical restrictions.

Conflicts of Interest: The authors declare no conflict of interest.

\section{References}

1. Bronte, V.; Zanovello, P. Regulation of immune responses by L-arginine metabolism. Nat. Rev. Immunol. 2005, 5, 641-654. [CrossRef] [PubMed]

2. Sagar, N.A.; Tarafdar, S.; Agarwal, S.; Tarafdar, A.; Sharma, S. Polyamines: Functions, Metabolism, and Role in Human Disease Management. Med. Sci. 2021, 9, 44. [CrossRef] [PubMed]

3. Zarza, X.; Van Wijk, R.; Shabala, L.; Hunkeler, A.; Lefebvre, M.; Rodriguez-Villalón, A.; Shabala, S.; Tiburcio, A.F.; Heilmann, I.; Munnik, T. Lipid kinases PIP5K7 and PIP5K9 are required for polyamine-triggered K(+) efflux in Arabidopsis roots. Plant J. 2020, 104, 416-432. [CrossRef] [PubMed]

4. Dhara, M.; Matta, J.A.; Lei, M.; Knowland, D.; Yu, H.; Gu, S.; Bredt, D.S. Polyamine regulation of ion channel assembly and implications for nicotinic acetylcholine receptor pharmacology. Nat. Commun. 2020, 11, 2799. [CrossRef]

5. Prusov, A.N.; Smirnova, T.A.; Kolomijtseva, G.Y. Thermodynamic Study of Interactions of Distamycin A with Chromatin in Rat Liver Nuclei in the Presence of Polyamines. Biochemistry (Moscow) 2018, 83, 1231-1244. [CrossRef] [PubMed]

6. Sakamoto, A.; Terui, Y.; Uemura, T.; Igarashi, K.; Kashiwagi, K. Polyamines regulate gene expression by stimulating translation of histone acetyltransferase mRNAs. J. Biol. Chem. 2020, 295, 8736-8745. [CrossRef] [PubMed]

7. Zhang, H.; Alsaleh, G.; Feltham, J.; Sun, Y.; Napolitano, G.; Riffelmacher, T.; Charles, P.; Frau, L.; Hublitz, P.; Yu, Z.; et al. Polyamines Control eIF5A Hypusination, TFEB Translation, and Autophagy to Reverse B Cell Senescence. Mol. Cell 2019, 76, 110-125.e9. [CrossRef]

8. Dever, T.E.; Ivanov, I.P. Roles of polyamines in translation. J. Biol. Chem. 2018, 293, 18719-18729. [CrossRef]

9. Yoshida, T.; Sakamoto, A.; Terui, Y.; Takao, K.; Sugita, Y.; Yamamoto, K.; Ishihama, A.; Igarashi, K.; Kashiwagi, K. Effect of Spermidine Analogues on Cell Growth of Escherichia coli Polyamine Requiring Mutant MA261. PLoS ONE 2016, 11, e0159494. [CrossRef]

10. Igarashi, K.; Kashiwagi, K. Modulation of cellular function by polyamines. Int. J. Biochem. Cell Biol. 2010, 42, 39-51. [CrossRef]

11. Lee, C.-Y.; Su, G.-C.; Huang, W.-Y.; Ko, M.-Y.; Yeh, H.-Y.; Chang, G.-D.; Lin, S.-J.; Chi, P. Promotion of homology-directed DNA repair by polyamines. Nat. Commun. 2019, 10, 65. [CrossRef] [PubMed]

12. Snyder, R.D.; Sunkara, P.S. Effect of polyamine depletion on DNA damage and repair following UV irradiation of HeLa cells. Photochem. Photobiol. 1990, 52, 525-532. [CrossRef] [PubMed]

13. Tanaka, H.; Takeda, K.; Imai, A. Polyamines alleviate the inhibitory effect of the DNA cross-linking agent mitomycin C on root growth. Plant Signal. Behav. 2019, 14, 1659687. [CrossRef] [PubMed]

14. Becciolini, A.; Porciani, S.; Lanini, A.; Balzi, M.; Cionini, L.; Bandettini, L. Polyamine levels in healthy and tumor tissues of patients with colon adenocarcinoma. Dis. Colon Rectum 1991, 34, 167-173. [CrossRef]

15. Li, J.; Meng, Y.; Wu, X.; Sun, Y. Polyamines and related signaling pathways in cancer. Cancer Cell Int. 2020, 20, 539. [CrossRef]

16. Nowotarski, S.L.; Woster, P.M.; Casero, R.A.J. Polyamines and cancer: Implications for chemotherapy and chemoprevention. Expert Rev. Mol. Med. 2013, 15, e3. [CrossRef]

17. Casero, R.A.J.; Murray Stewart, T.; Pegg, A.E. Polyamine metabolism and cancer: Treatments, challenges and opportunities. Nat. Rev. Cancer 2018, 18, 681-695. [CrossRef]

18. Hesterberg, R.S.; Cleveland, J.L.; Epling-Burnette, P.K. Role of Polyamines in Immune Cell Functions. Med. Sci. 2018, 6, 22. [CrossRef]

19. Carriche, G.M.; Almeida, L.; Stüve, P.; Velasquez, L.; Dhillon-LaBrooy, A.; Roy, U.; Lindenberg, M.; Strowig, T.; Plaza-Sirvent, C.; Schmitz, I.; et al. Regulating T-cell differentiation through the polyamine spermidine. J. Allergy Clin. Immunol. 2021, 147, 335-348.e11. [CrossRef]

20. Agostinelli, E.; Belli, F.; Molinari, A.; Condello, M.; Palmigiani, P.; Vedova, L.D.; Marra, M.; Seiler, N.; Arancia, G. Toxicity of enzymatic oxidation products of spermine to human melanoma cells (M14): Sensitization by heat and MDL 72527. Biochim. Biophys. Acta 2006, 1763, 1040-1050. [CrossRef] 
21. Murray Stewart, T.; Dunston, T.T.; Woster, P.M.; Casero, R.A.J. Polyamine catabolism and oxidative damage. J. Biol. Chem. 2018, 293, 18736-18745. [CrossRef] [PubMed]

22. Wang, L.; Liu, Y.; Qi, C.; Shen, L.; Wang, J.; Liu, X.; Zhang, N.; Bing, T.; Shangguan, D. Oxidative degradation of polyamines by serum supplement causes cytotoxicity on cultured cells. Sci. Rep. 2018, 8, 10384. [CrossRef]

23. Pegg, A.E. Toxicity of polyamines and their metabolic products. Chem. Res. Toxicol. 2013, 26, 1782-1800. [CrossRef] [PubMed]

24. Tirtom, N.E.; Hsu, Y.; Li, H.-W. Polyamines stimulate RecA-mediated recombination by condensing duplex DNA and stabilizing intermediates. Phys. Chem. Chem. Phys. 2020, 22, 11928-11935. [CrossRef]

25. Miller-Fleming, L.; Olin-Sandoval, V.; Campbell, K.; Ralser, M. Remaining Mysteries of Molecular Biology: The Role of Polyamines in the Cell. J. Mol. Biol. 2015, 427, 3389-3406. [CrossRef]

26. Landau, G.; Bercovich, Z.; Park, M.H.; Kahana, C. The role of polyamines in supporting growth of mammalian cells is mediated through their requirement for translation initiation and elongation. J. Biol. Chem. 2010, 285, 12474-12481. [CrossRef]

27. Huang, Y.; Marton, L.J.; Woster, P.M.; Casero, R.A. Polyamine analogues targeting epigenetic gene regulation. Essays Biochem. 2009, 46, 95-110. [CrossRef]

28. Bonilla, B.; Hengel, S.R.; Grundy, M.K.; Bernstein, K.A. RAD51 Gene Family Structure and Function. Annu. Rev. Genet. 2020, 54, 25-46. [CrossRef]

29. Smith, P.J.; Zhang, C.; Wang, J.; Chew, S.L.; Zhang, M.Q.; Krainer, A.R. An increased specificity score matrix for the prediction of SF2/ASF-specific exonic splicing enhancers. Hum. Mol. Genet. 2006, 15, 2490-2508. [CrossRef]

30. Cartegni, L.; Wang, J.; Zhu, Z.; Zhang, M.Q.; Krainer, A.R. ESEfinder: A web resource to identify exonic splicing enhancers. Nucleic Acids Res. 2003, 31, 3568-3571. [CrossRef]

31. Jurica, M.S.; Moore, M.J. Pre-mRNA splicing: Awash in a sea of proteins. Mol. Cell 2003, 12, 5-14. [CrossRef]

32. Lee, Y.; Rio, D.C. Mechanisms and Regulation of Alternative Pre-mRNA Splicing. Annu. Rev. Biochem. 2015, 84, 291-323. [CrossRef]

33. Savisaar, R.; Hurst, L.D. Exonic splice regulation imposes strong selection at synonymous sites. Genome Res. 2018, 28, 1442-1454. [CrossRef]

34. Sohail, M.; Xie, J. Diverse regulation of $3^{\prime}$ splice site usage. Cell. Mol. Life Sci. 2015, 72, 4771-4793. [CrossRef]

35. Liu, L.F.; Rowe, T.C.; Yang, L.; Tewey, K.M.; Chen, G.L. Cleavage of DNA by mammalian DNA topoisomerase II. J. Biol. Chem. 1983, 258, 15365-15370. [CrossRef]

36. Tewey, K.M.; Rowe, T.C.; Yang, L.; Halligan, B.D.; Liu, L.F. Adriamycin-induced DNA damage mediated by mammalian DNA topoisomerase II. Science 1984, 226, 466-468. [CrossRef] [PubMed]

37. Sedletska, Y.; Giraud-Panis, M.-J.; Malinge, J.-M. Cisplatin is a DNA-damaging antitumour compound triggering multifactorial biochemical responses in cancer cells: Importance of apoptotic pathways. Curr. Med. Chem. Anticancer Agents 2005, 5, 251-265. [CrossRef] [PubMed]

38. Zhdanov, D.D.; Vasina, D.A.; Orlova, V.S.; Orlova, E.V.; Grishin, D.V.; Gladilina, Y.A.; Pokrovskaya, M.V.; Aleksandrova, S.S.; Sokolov, N.N. Induction of Apoptotic Endonuclease EndoG with DNA-Damaging Agents Initiates Alternative Splicing of Telomerase Catalytic Subunit hTERT and Inhibition of Telomerase Activity hTERT in Human CD4 ${ }^{+}$and CD8 ${ }^{+} \mathrm{T}$ Lymphocytes. Biochem. (Moscow) Suppl. Ser. B Biomed. Chem. 2018, 12, 217-230. [CrossRef]

39. Xu, Y.; Villalona-Calero, M.A. Irinotecan: Mechanisms of tumor resistance and novel strategies for modulating its activity. Ann. Oncol. Off. J. Eur. Soc. Med. Oncol. 2002, 13, 1841-1851. [CrossRef] [PubMed]

40. Wood, J.P.; Smith, A.J.O.; Bowman, K.J.; Thomas, A.L.; Jones, G.D.D. Comet assay measures of DNA damage as biomarkers of irinotecan response in colorectal cancer in vitro and in vivo. Cancer Med. 2015, 4, 1309-1321. [CrossRef] [PubMed]

41. Douki, T.; Bretonniere, Y.; Cadet, J. Protection against radiation-induced degradation of DNA bases by polyamines. Radiat. Res. 2000, 153, 29-35. [CrossRef]

42. Zahedi, K.; Bissler, J.J.; Wang, Z.; Josyula, A.; Lu, L.; Diegelman, P.; Kisiel, N.; Porter, C.W.; Soleimani, M. Spermidine/spermine $N^{1}$-acetyltransferase overexpression in kidney epithelial cells disrupts polyamine homeostasis, leads to DNA damage, and causes $\mathrm{G}_{2}$ arrest. Am. J. Physiol. Cell Physiol. 2007, 292, C1204-C1215. [CrossRef]

43. TABOR, H. The protective effect of spermine and other polyamines against heat denaturation of deoxyribonucleic acid. Biochemistry 1962, 1, 496-501. [CrossRef]

44. Feuerstein, B.G.; Williams, L.D.; Basu, H.S.; Marton, L.J. Implications and concepts of polyamine-nucleic acid interactions. J. Cell. Biochem. 1991, 46, 37-47. [CrossRef]

45. Warters, R.L.; Newton, G.L.; Olive, P.L.; Fahey, R.C. Radioprotection of human cell nuclear DNA by polyamines: Radiosensitivity of chromatin is influenced by tightly bound spermine. Radiat. Res. 1999, 151, 354-362. [CrossRef] [PubMed]

46. Newton, G.L.; Aguilera, J.A.; Ward, J.F.; Fahey, R.C. Effect of polyamine-induced compaction and aggregation of DNA on the formation of radiation-induced strand breaks: Quantitative models for cellular radiation damage. Radiat. Res. 1997, 148, 272-284. [CrossRef] [PubMed]

47. Park, J.-Y.; Yoo, H.-W.; Kim, B.-R.; Park, R.; Choi, S.-Y.; Kim, Y. Identification of a novel human Rad51 variant that promotes DNA strand exchange. Nucleic Acids Res. 2008, 36, 3226-3234. [CrossRef]

48. Kawabata, M.; Akiyama, K.; Kawabata, T. Genomic structure and multiple alternative transcripts of the mouse TRAD/RAD51L3/ RAD51D gene, a member of the recA/RAD51 gene family. Biochim. Biophys. Acta 2004, 1679, 107-116. [CrossRef] 
49. Wang, A.T.; Kim, T.; Wagner, J.E.; Conti, B.A.; Lach, F.P.; Huang, A.L.; Molina, H.; Sanborn, E.M.; Zierhut, H.; Cornes, B.K.; et al. A Dominant Mutation in Human RAD51 Reveals Its Function in DNA Interstrand Crosslink Repair Independent of Homologous Recombination. Mol. Cell 2015, 59, 478-490. [CrossRef]

50. Matsuo, Y.; Sakane, I.; Takizawa, Y.; Takahashi, M.; Kurumizaka, H. Roles of the human Rad51 L1 and L2 loops in DNA binding. FEBS J. 2006, 273, 3148-3159. [CrossRef]

51. Ameziane, N.; May, P.; Haitjema, A.; van de Vrugt, H.J.; van Rossum-Fikkert, S.E.; Ristic, D.; Williams, G.J.; Balk, J.; Rockx, D.; Li, H.; et al. A novel Fanconi anaemia subtype associated with a dominant-negative mutation in RAD51. Nat. Commun. 2015, 6, 8829. [CrossRef] [PubMed]

52. Baldock, R.A.; Pressimone, C.A.; Baird, J.M.; Khodakov, A.; Luong, T.T.; Grundy, M.K.; Smith, C.M.; Karpenshif, Y.; BrattonPalmer, D.S.; Prakash, R.; et al. RAD51D splice variants and cancer-associated mutations reveal XRCC2 interaction to be critical for homologous recombination. DNA Repair 2019, 76, 99-107. [CrossRef] [PubMed]

53. Kalvala, A.; Gao, L.; Aguila, B.; Reese, T.; Otterson, G.A.; Villalona-Calero, M.A.; Duan, W. Overexpression of Rad51C splice variants in colorectal tumors. Oncotarget 2015, 6, 8777-8787. [CrossRef] [PubMed]

54. Bueno-Martínez, E.; Sanoguera-Miralles, L.; Valenzuela-Palomo, A.; Lorca, V.; Gómez-Sanz, A.; Carvalho, S.; Allen, J.; Infante, M.; Pérez-Segura, P.; Lázaro, C.; et al. RAD51D Aberrant Splicing in Breast Cancer: Identification of Splicing Regulatory Elements and Minigene-Based Evaluation of 53 DNA Variants. Cancers 2021, 13, 2845. [CrossRef]

55. Cáceres, J.F.; Krainer, A.R. Functional analysis of pre-mRNA splicing factor SF2/ASF structural domains. EMBO J. 1993, 12, 4715-4726. [CrossRef]

56. Raderschall, E.; Stout, K.; Freier, S.; Suckow, V.; Schweiger, S.; Haaf, T. Elevated levels of Rad51 recombination protein in tumor cells. Cancer Res. 2002, 62, 219-225.

57. Klein, H.L. The consequences of Rad51 overexpression for normal and tumor cells. DNA Repair 2008, 7, 686-693. [CrossRef]

58. Richardson, C.; Stark, J.M.; Ommundsen, M.; Jasin, M. Rad51 overexpression promotes alternative double-strand break repair pathways and genome instability. Oncogene 2004, 23, 546-553. [CrossRef]

59. Son, M.Y.; Hasty, P. Homologous recombination defects and how they affect replication fork maintenance. AIMS Genet. 2018, 5 , 192-211. [CrossRef]

60. Laurini, E.; Marson, D.; Fermeglia, A.; Aulic, S.; Fermeglia, M.; Pricl, S. Role of Rad51 and DNA repair in cancer: A molecular perspective. Pharmacol. Ther. 2020, 208, 107492. [CrossRef]

61. van Zuylen, L.; Bridgewater, J.; Sparreboom, A.; Eskens, F.A.L.M.; de Bruijn, P.; Sklenar, I.; Planting, A.S.T.; Choi, L.; Bootle, D.; Mueller, C.; et al. Phase I and pharmacokinetic study of the polyamine synthesis inhibitor SAM486A in combination with 5-fluorouracil/leucovorin in metastatic colorectal cancer. Clin. Cancer Res. Off. J. Am. Assoc. Cancer Res. 2004, 10, 1949-1955. [CrossRef]

62. Hahm, H.A.; Dunn, V.R.; Butash, K.A.; Deveraux, W.L.; Woster, P.M.; Casero, R.A.J.; Davidson, N.E. Combination of standard cytotoxic agents with polyamine analogues in the treatment of breast cancer cell lines. Clin. cancer Res. Off. J. Am. Assoc. Cancer Res. 2001, 7, 391-399.

63. Zhdanov, D.D.; Gladilina, Y.A.; Grishin, D.V.; Grachev, V.A.; Orlova, V.S.; Pokrovskaya, M.V.; Alexandrova, S.S.; Pokrovsky, V.S.; Sokolov, N.N. Contact-independent suppressive activity of regulatory T cells is associated with telomerase inhibition, telomere shortening and target lymphocyte apoptosis. Mol. Immunol. 2018, 101, 229-244. [CrossRef] [PubMed]

64. Zhdanov, D.D.; Gladilina, Y.A.; Pokrovsky, V.S.; Grishin, D.V.; Grachev, V.A.; Orlova, V.S.; Pokrovskaya, M.V.; Alexandrova, S.S.; Sokolov, N.N. Murine regulatory T cells induce death of effector T, B, and NK lymphocytes through a contact-independent mechanism involving telomerase suppression and telomere-associated senescence. Cell. Immunol. 2018, 331, 146-160. [CrossRef] [PubMed]

65. Denizot, F.; Lang, R. Rapid colorimetric assay for cell growth and survival. Modifications to the tetrazolium dye procedure giving improved sensitivity and reliability. J. Immunol. Methods 1986, 89, 271-277. [CrossRef]

66. Zhdanov, D.D.; Pokrovsky, V.S.; Pokrovskaya, M.V.; Alexandrova, S.S.; Eldarov, M.A.; Grishin, D.V.; Basharov, M.M.; Gladilina, Y.A.; Podobed, O.V.; Sokolov, N.N. Inhibition of telomerase activity and induction of apoptosis by Rhodospirillum rubrum L-asparaginase in cancer Jurkat cell line and normal human CD4+ T lymphocytes. Cancer Med. 2017, 6, 2697-2712. [CrossRef]

67. Darzynkiewicz, Z.; Galkowski, D.; Zhao, H. Analysis of apoptosis by cytometry using TUNEL assay. Methods 2008, 44, 250-254. [CrossRef]

68. Zhdanov, D.D.; Vasina, D.A.; Orlova, E.V.; Orlova, V.S.; Pokrovsky, V.S.; Pokrovskaya, M.V.; Aleksandrova, S.S.; Sokolov, N.N. Cisplatin-induced apoptotic endonuclease EndoG inhibits telomerase activity and causes malignant transformation of human CD4+ T lymphocytes. Biochem. (Moscow) Suppl. Ser. B Biomed. Chem. 2017, 11, 251-264. [CrossRef]

69. Baker, B.F.; Lot, S.S.; Condon, T.P.; Cheng-Flournoy, S.; Lesnik, E.A.; Sasmor, H.M.; Bennett, C.F. 2'-O-(2-Methoxy)ethyl-modified anti-intercellular adhesion molecule 1 (ICAM-1) oligonucleotides selectively increase the ICAM-1 mRNA level and inhibit formation of the ICAM-1 translation initiation complex in human umbilical vein endothelial cells. J. Biol. Chem. 1997, 272, 11994-12000. [CrossRef]

70. Vasina, D.A.; Zhdanov, D.D.; Orlova, E.V.; Orlova, V.S.; Pokrovskaya, M.V.; Aleksandrova, S.S.; Sokolov, N.N. Apoptotic endonuclease EndoG inhibits telomerase activity and induces malignant transformation of human CD4+ T cells. Biochemistry (Moscow) 2017, 82, 24-37. [CrossRef] 
71. Laemmli, U.K. Cleavage of structural proteins during the assembly of the head of bacteriophage T4. Nature 1970, $227,680-685$. [CrossRef] [PubMed]

72. Hofnagel, O.; Luechtenborg, B.; Stolle, K.; Lorkowski, S.; Eschert, H.; Plenz, G.; Robenek, H. Proinflammatory cytokines regulate LOX-1 expression in vascular smooth muscle cells. Arterioscler. Thromb. Vasc. Biol. 2004, 24, 1789-1795. [CrossRef] [PubMed] 